\title{
Estimation of Tsunami Inundation and Disaster Mitigation in Bulukumba, Indonesia
}

\author{
Estimasi Kawasan Terdampak Tsunami dan Mitigasi Bencana Kabupaten Bulukumba, Indonesia
}

\author{
Imanuela Indah Pertiwi ${ }^{1 *}$, M. Hattah Fattah ${ }^{2}$, Abdul Rauf $^{2}$ \\ ${ }^{1}$ Badan Meteorologi, Klimatologi, dan Geofisika Wilayah IV Makassar, Indonesia \\ ${ }^{2}$ Universitas Muslim Indonesia, Makassar, Indonesia \\ *Email: imanuela.indah@gmail.com
}

Submit 08-05-2017; Revised 30-11-2017; Accepted 05-12-2017

\begin{abstract}
The study aims to determine the potential of earthquake that could lead to tsunamis in the Flores Sea. Furthermore, based on the potential of earthquake magnitude, can be known high run-up of tsunami in the southern coastal region of Bulukumba regency. The height run-up of tsunami can show the vulnerability of tsunami impact and effects spatially based on the effect of land function in the southern coastal area of Bulukumba Regency. To plan an effective mitigation scenario in the southern coastal area of Bulukumba Regency can be based on the vulnerability of tsunami impacts and effects. This study uses secondary data consisting of three data. The condition of land function and the density of community infrastructure is obtained based on RTRW data of Bulukumba District and Satellite Bing Maps image data; historical data of earthquake events in the Flores Sea from 1927 to 2016 from the USGS site, and BMKG; as well as topographic data. Field check activity on land function condition is done as a form of conformity of secondary data. The results showed that the potential of seismicity in the Flores Sea is high, with magnitude (M 7 SR) potentially causing tsunamis around it, not least Bulukumba Regency, South Sulawesi Province, Indonesia. The area of tsunami inundation in Bulukumba Regency is $13.617 \mathrm{~km}^{2}$. The coastal area of Ujungbulu sub-district is a dense residential area that has the highest risk to the tsunami with an estimated $3,331 \mathrm{~km}^{2}$ inundation. Land cover in Bontotiro sub-district dominated by vegetation with kerapatandengan interval distance of more than $3 \mathrm{~m}$ is seen able to reduce the tsunami with a height of $17 \mathrm{~m}$ and $25 \mathrm{~m}$. Tsunami disaster mitigation scenario in Bulukumba regency is to make coastal area as conservation area of coastal forest (mangrove plant) that function as green belt of tsunami wave holder.

Keywords: Magnitude, Tsunami, Topography, Land function, Inundation
\end{abstract}

Abstrak: Penelitian bertujuan untuk mengetahui potensi kegempaan yang dapat menimbulkan tsunami di Laut Flores. Selanjutnya berdasarkan pada potensi magnitude gempabumi, dapat diketahui tinggi run-up tsunami di wilayah pesisir selatan Kabupaten Bulukumba. Tinggi runup tsunami dapat menunjukkan kerentanan dampak/efek tsunami secara spasial berdasarkan pengaruh fungsi lahan di wilayah pesisir selatan Kabupaten Bulukumba. Perencanaan skenario mitigasi yang efektif di wilayah pesisir selatan Kabupaten Bulukumba dapat dilakukan berdasarkan kerentanan dampak/efek tsunami. Penelitian ini menggunakan data sekunder yang terdiri dari tiga data. Kondisi fungsi lahan serta kepadatan infrastruktur masyarakat diperoleh berdasarkan data RTRW Kabupaten Bulukumba dan data citra Satelit Bing Maps; data historis kejadian gempabumi di Laut Flores tahun 1927 sampai 2016 dari situs USGS, dan BMKG; serta data topografi. Kegiatan cek lapangan terhadap kondisi fungsi lahan dilakukan sebagai bentuk kesesuaian dari data sekunder. Hasil penelitian menunjukkan potensi kegempaan di Laut Flores adalah tinggi, dengan magnitude (M $7 \mathrm{SR}$ ) yang berpotensi menimbulkan tsunami di sekitarnya, tidak terkecuali Kabupaten Bulukumba, Provinsi Sulawesi Selatan, Indonesia. Luas area inundasi tsunami di Kabupaten Bulukumba yaitu $13,617 \mathrm{~km}^{2}$. Wilayah pesisir Kecamatan Ujungbulu merupakan area pemukiman padat yang memiliki resiko tertinggi terhadap tsunami dengan estimasi genangan seluas $3,331 \mathrm{~km}^{2}$. Tutupan lahan di Kecamatan Bontotiro yang didominasi vegetasi dengan interval jarak lebih dari $3 \mathrm{~m}$ terlihat mampu meredam tsunami dengan ketinggian $17 \mathrm{~m}$ dan $25 \mathrm{~m}$. Skenario mitigasi bencana tsunami di Kabupaten Bulukumba yaitu menjadikan wilayah pesisir untuk sebagai kawasan konservasi hutan pantai (tanaman mangrove) yang berfungsi sebagai sabuk hijau penahan gelombang tsunami.

Katakunci: Magnitude, Tsunami, Topografi, Fungsi Lahan, Inundasi

\section{PENDAHULUAN}

Indonesia yang terletak pada batas pertemuan tiga lempeng tektonik bumi yang sangat aktif merupakan wilayah sangat rawan terhadap gempa-gempa tektonik. Di Indonesia terdapat beberapa kelompok pantai yang rawan bencana tsunami, yaitu kelompok pantai barat Sumatera, pantai selatan Pulau Jawa, pantai utara dan selatan pulau-pulau Nusa Tenggara, pulau-pulau di Maluku, pantai utara Irian Jaya, dan hampir seluruh pantai di Sulawesi (Diposaptono, 
2003). Secara geografis sebelah selatan Provinsi Sulawesi Selatan berbatasan langsung dengan Laut Flores yang memiliki sesar aktif yang memanjang dari pantai utara Lombok hingga sebelah timur laut Bali (Yasid,1999). Sesar aktif ini dikenal sebagai Back Arc Thrust (sesar naik belakang busur kepulauan). Aktivitas dari sesar naik belakang busur kepulauan ini yang menyebabkan gempabumi banyak terjadi di utara kepulauan Sumbawa hingga Flores. Pada tahun 1820, tepatnya 29 Desember, gempa berkekuatan 7,5 SR yang berpusat di Laut Flores (koordinat $7^{\circ} \mathrm{LS} \quad 119^{\circ} \mathrm{BT}$ ) mengguncang Sumbawa sampai Sulawesi. Gempa tersebut menyebabkan ketinggian tsunami sebesar $25 \mathrm{~m}$ sehingga menyapu pelabuhan Bulukumba dengan korban jiwa diperkirakan sebanyak 500 orang yang tenggelam (Wichmann (1918), Sieberg (1932), dan Heck (1947)).

Tujuan dalam penelitian ini yaitu untuk mengetahui potensi kegempaan yang dapat menimbulkan tsunami di Laut Flores. Selanjutnya berdasarkan pada potensi magnitude gempabumi dapat diketahui tinggi run-up tsunami di wilayah pesisir selatan Kabupaten Bulukumba. Tinggi runup tsunami dapat menunjukkan kerentanan dampak/efek tsunami secara spasial berdasarkan pengaruh fungsi lahan di wilayah pesisir selatan Kabupaten Bulukumba. Perencanaan skenario mitigasi yang efektif di wilayah pesisir selatan Kabupaten Bulukumba dapat dilakukan berdasarkan kerentanan dampak/efek tsunami.

Wilayah pesisir selatan Kabupaten Bulukumba merupakan pesisir yang letaknya berbatasan langsung dengan Laut Flores. Keadaan tektonik yang membentuk Laut Flores menjadikannya sebagai salah satu daerah yang memiliki aktivitas seismik yang sangat besar. Gempa yang terjadi di selatan pulau Sulawesi pada umumnya merupakan gempa dengan kekuatan yang besar dan kedalaman yang dangkal (Database Tsunami Internasional). Batas bawah periode kembalinya seismisitas di Laut Flores diperkirakan 4 tahun untuk gempabumi 7.8 SR dan 16 tahun untuk gempabumi 8.4 SR. Berdasarkan sebuah sumber ilmiah sebelumnya menyatakan bahwa tidak ada gempabumi yang jelas terkait dengan Patahan busur belakang yang telah ditemukan berkedalaman lebih dari $25 \mathrm{~km}$ (McCaffrey dan Nabelek, 1987).

Karakteristik gempa-gempa yang terjadi tersebut sangat berpotensi menimbulkan tsunami. Gempabumi yang terjadi memiliki periode ulang untuk terjadi lagi, sehingga dilakukan perhitungan periode ulang gempabumi di Laut Flores yang berpotensi menimbulkan tsunami. Letaknya yang berbatasan langsung dengan Laut Flores, maka wilayahwilayah pesisir di Kabupaten Bulukumba sangat memungkinkan mendapatkan tsunami kiriman (imbas tsunami) dari kejadian-kejadian di Laut Flores.

Back arc thrust membujur di Laut Flores sejajar dengan busur Kepulauan Bali dan Nusa Tenggara dalam bentuk segmen-segmen, terdapat segmen utama maupun segmen minor. Berdasarkan data, sebagian besar gempa terasa hingga gempa merusak yang mengguncang Bali, Nusa Tenggara Barat, dan NTT disebabkan oleh aktivitas back arc thrust ini, dan hanya sebagian kecil saja disebabkan oleh aktivitas penyusupan lempeng. Flores Thrust dikenal sebagai generator gempa- gempa merusak yang akan terus-menerus mengancam untuk mengguncang busur kepulauan. Zona sesar naik terbagi ke dalam dua segmen yaitu zona sesar naik Flores di barat dan zona sesar naik Wetar di timur. Namun, di jalur sepanjang $500 \mathrm{~km}$ ini, terjadi jejak-jejak patahan yang relatif pendek (20-30 km panjang), yang menunjukkan berbagai kondisi tektonik dan probabilitas gempabumi.

Dalam jurnal Geoscience Australia, Indonesias Historical Earthquake, diuraikan bahwa pada tanggal 29 Desember tahun 1820, terjadi gempabumi yang menghasilkan run-up tsunami yang besar di beberapa lokasi, membentang dari Sumenep (Jawa) ke beberapa daerah di sepanjang pantai selatan Sulawesi. Pada Bima (Sumbawa), gempa berlangsung lebih dari dua menit, diikuti oleh tsunami kuat yang menghempaskan kapal yang berlabuh di teluk sampai jauh ke pedalaman, rumah dan pohon-pohon tumbang, dan menyebabkan banyak struktur batu yang runtuh (Reinwardt, 1858). Setelah gelombang tsunami, lumpur menutupi tanah dan rumah, serta beberapa orang tewas akibat runtuhnya bangunan. Di Makassar, Sulawesi Selatan, gempa berlangsung dua setengah menit (Bataviashe Courant 28 April 1821) yang juga dirasakan di tempat-tempat lain di pantai selatan Sulawesi. Tsunami menghancurkan desadesa di barat Bontain (Bonthain) sampai timur Bulukumba, termasuk desa Terang-Terang dan Nipa-Nipa (Roorda van Eysinga, 1830). Pada Bulukumba (Sulawesi Selatan), gempa berlangsung sekitar 4-5 menit (Roorda van Eysinga, 1830). Gempa itu disertai dengan gelombang tsunami yang merendam daratan sejauh 350-450 m (Roorda van Eysinga, 1830). Beberapa kendaraan terlempar dari pantai ke sawah, dan barak benteng hancur. Sebagai hasil dari tsunami, 400-500 orang meninggal (Roorda van Eysinga, 1830).

Daerah dataran rendah di Kabupaten Bulukumba dengan ketinggian antara $0-25 \mathrm{~m}$ di atas permukaan laut meliputi tujuh kecamatan pesisir, yaitu Kecamatan Gantarang, Kecamatan Ujungbulu, Kecamatan Ujung Loe, Kecamatan Bontobahari, Kecamatan Bontotiro, Kecamatan Kajang, dan Kecamatan Herlang. Daerah berbukit dengan ketinggian antara $25-100 \mathrm{~m}$ dari permukaan laut meliputi bagian dari Kecamatan Gantarang, Kecamatan Kindang, Kecamatan Bontobahari, Kecamatan Bontotiro, Kecamatan Kajang, Kecamatan Herlang, Kecamatan Bulukumpa, dan Kecamatan Rilau Ale. Daerah perbukitan di Kabupaten Bulukumba terbentang mulai dari Barat ke Utara dengan ketinggian 100 sampai diatas $500 \mathrm{~m}$ dari permukaan laut meliputi bagian dari Kecamatan Kindang, Kecamatan Bulukumpa, dan Kecamatan Rilau Ale. Wilayah Kabupaten Bulukumba lebih didominasi dengan keadaan topografi dataran rendah sampai berbukit. Luas dataran rendah sampai berbukit dan dataran tinggi hampir berimbang, yaitu jika dataran rendah sampai berbukit mencapai sekitar 50,28\% maka dataran tinggi mencapai 49,72\%. Ada empat hal penting dalam mitigasi bencana, yaitu: (1) Tersedia informasi dan peta kawasan rawan bencana untuk tiap jenis bencana, (2) Sosialisasi untuk meningkatkan pemahaman dan kesadaran masyarakat dalam menghadapi bencana, karena bermukim di daerah rawan bencana, (3) Mengetahui apa yang perlu dilakukan dan dihindari, serta mengetahui cara penyelamatan diri jika bencana timbul, (4) Mengetahui pengaturan dan penataan kawasan rawan bencana untuk mengurangi ancaman bencana.

Untuk memodelkan gelombang tsunami terdiri dari dua yaitu gempabumi yang pernah terjadi di Laut Flores yang berpotensi menimbulkan tsunami tanggal 3 Maret 1927 dan gempabumi yang menimbulkan tsunami tanggal 29 Desember tahun 1820. Hasil yang diperoleh dari perhitungan 


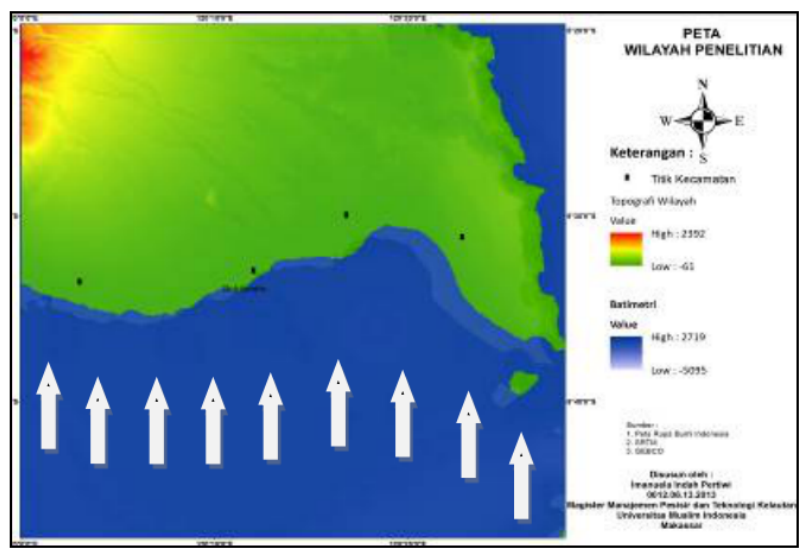

Gambar 1. Peta wilayah penelitian.

adalah estimasi tinggi run-up tsunami di darat sekitar sumber gempa. Berdasarkan estimasi tinggi run-up tsunami disertai dengan data topografi, dan peruntukan fungsi lahan wilayah pesisir selatan Kabupaten Bulukumba, dapat dimodelkan potensi genangan tsunami dengan metode pengurangan tinggi run-up ke arah daratan. Luas area rendaman (inundasi) dihitung dengan bantuan software MapInfo 10.0. Peta potensi genangan tsunami selanjutnya digunakan untuk menyusun skenario mitigasi yang efektif di wilayah pesisir selatan Kabupaten Bulukumba.

\section{METODA PENELITIAN}

Lokasi penelitian potensi genangan tsunami ini terletak di wilayah pesisir selatan Kabupaten Bulukumba yang dibatasi pada koordinat $5^{\circ} 20 \mathrm{LS} 5^{\circ} 46 \mathrm{LS}$ dan $120^{\circ} 04 \mathrm{BT} 120^{\circ} 24$ BT. Terdapat empat kecamatan dengan kategori fungsi lahan yang berbeda, yang berbatasan langsung dengan Laut Flores yang ditunjukkan dengan titik hitam pada Gambar 1. Tanda panah pada gambar menunjukkan arah datang gelombang tsunami yang diasumsikan tegak lurus terhadap garis pantai. Penelitian ini dilaksanakan pada bulan Februari sampai Oktober tahun 2016.

\subsection{Potensi Kejadian Gempabumi}

Potensi kejadian gempabumi yang dapat menimbulkan tsunami di Laut Flores dapat diketahui dengan metode Likelihood. Fungsi likelihood merupakan suatu metode statistik yang sangat sesuai untuk memecahkan beberapa masalah tentang seismologi. Menurut Aki (1965) bahwa metode ini dipergunakan untuk masalah antara frekuensi gempa dari magnitude. Metode untuk mengetahui param kegempaan suatu wilayah adalah dengan hubungan Gutenberg-Richter yang dituliskan sebagai :

$$
\log N(M)=a_{1}-b M
$$

dimana adalah jumlah kumulatif gempabumi dengan magnitude lebih besar atau sama dengan M, sedangkan a dan $b$ adalah konstanta yang disebut sebagai paramparam kegempaan yang ditentukan dengan metode maxi- mum likelihood. Metode maximum likelihood menggunakan persamaan berikut:

$$
\begin{gathered}
b=\frac{\log e}{\bar{M}-M_{\min }}=\frac{0.4343}{\bar{M}-M_{\min }} \\
a=\log N\left(M \geq M_{o}\right)+\log (b \ln 10)+M_{o b}
\end{gathered}
$$

Sehingga, $a_{1}=a-\log T$

Keterangan:

$\bar{M}$ : magnitudo rata-rata dari data gempa, $M_{\min }=$ magnitudo minimum, $M_{o}=$ magnitude terkecil dalam wilayah penelitian yang akan dihitung koefisien seismisitasnya, dan $T=$ rentang tahun data yang digunakan.

Jumlah frekuensi kumulatif gempabumi per tahun atau disebut sebagai indeks seismisitas adalah:

$$
N(M)=10^{a_{1}-b M}
$$

Dengan diperoleh $N_{1}(M)$, maka dapat dihitung kemungkinan waktu terjadinya kembali (periode ulang $=\theta$ ) gempabumi merusak, yaitu:

$$
\theta=\frac{1}{N_{1}(M)} \text { tahun }
$$

Dalam penelitian ini akan ditentukan kemungkinan periode ulang terjadinya gempabumi yang berpotensi menimbulkan tsunami yaitu $\theta(\mathrm{M}=7.1), \theta(\mathrm{M}=7.5)$.

\subsection{Perhitungan Tinggi Tsunami}

Penggenangan (inundation) didefinisikan sebagai maximum horizontal penetration of the tsunami from the shoreline, sehingga dapat diartikan sebagai jarak horizontal antara tempat yang tertutup air sebagai akibat penjalaran gelombang tsunami di sepanjang daratan terhadap titik acuan tertentu yang umumnya berupa garis pantai. Penggenangan maksimum umumnya diukur dari jarak horizontal penetrasi maksimum gelombang tsunami ke wilayah daratan hingga masing-masing garis pantai yang dilanda tsunami (IOC, 2008).

Abe (1993) memperkenalkan suatu cara empirik untuk menaksir tinggi rayapan ( $r u n$-up) Ht yang merupakan fungsi dari $M_{w}$ dan $\mathrm{R}$ dapat dinyatakan dengan persamaan :

$$
\log \left(H_{t}\right)=M_{w}-\log R-5,55+C
$$

dengan $\mathrm{C}$ adalah konstanta, $\mathrm{C}=0$ untuk fore arc dan $\mathrm{C}=$ 1 untuk back arc.

Untuk tsunami lokal, persamaan (6) menghasilkan nilai tinggi rayapan yang sangat besar, sehingga Abe memperkenalkan suatu cara untuk membatasi tinggi rayapan dengan mengganti $R=R_{o}$ dan persamaan menjadi:

$$
\log \left(R_{o}\right)=0,5 M_{w}-2,25
$$

Dengan mensubtitusikan persamaan (7) ke persamaan (6), diperoleh persamaan baru :

$$
\log \left(R_{o}\right)=0,5 M_{w}-3,3+C
$$


Tabel 1. Hubungan magnitudo dan tinggi tsunami di pantai (Iida, 1963)

\begin{tabular}{|l|r|}
\hline Magnitudo & Tinggi tsunami/H (meter) \\
Tsunami & $>32$ \\
\hline 5.0 & $24-32$ \\
4.5 & $16-24$ \\
4.0 & $12-16$ \\
3.5 & $8-12$ \\
3.0 & $6-8$ \\
2.5 & $4-6$ \\
2.0 & $3-4$ \\
1.5 & $2-3$ \\
1.0 & $1-1.5$ \\
0.0 & $0.75-1$ \\
-0.5 & $0.5-0.75$ \\
-1.0 & $0.3-0.5$ \\
-1.5 & $<0.3$ \\
-2.0 & \\
\hline
\end{tabular}

dimana $H_{r}=$ tinggi batas $(\mathrm{m})$

Sementara tinggi rayapan maksimum (Hm) dapat dinyatakan dengan persamaan:

$$
H_{m}=2 H_{r}
$$

Besarnya tinggi (run-up) tsunami di darat dipengaruhi oleh beberapa faktor, diantaranya yaitu: (1) Bentuk Pantai, (2) Kelandaian Pantai, (3) Vegetasi dan struktur penghalang di sekitar pantai, (4) Arah gelombang tsunami, dan (5) Efek pemantulan dari pulau lain.

Konsep magnitude tsunami sebagai skala kekuatan relatif dari tsunami dikemukakan pertama kali oleh ilmuwan Jepang, yang bernama Imamura (1949). Untuk menentukan besarnya magnitude tsunami, Iida-Imamura (1956) mendefinisikan magnitude tsunami yang referensinya untuk tsunami di Jepang sebagai :

$$
m={ }^{2} \log \eta_{\max }
$$

dengan $\mathrm{m}$ : magnitude tsunami (Imamura) dan $\eta_{\max }$ merupakan tinggi run-up tsunami (m).

Tinggi tsunami meskipun di darat (run-up) yang dihasilkan dari hasil perhitungan melalui persamaan (8): dengan skenario kasus terburuk, digunakan sebagai dasar untuk mengklasifikasikan potensi bahaya tsunami dan penggenangannya. Kelas ketinggian ditentukan secara kualitatif berdasarkan tingkat bahaya bagi manusia dan bangunan. Makin tinggi run-up tsunami, makin berbahaya bagi manusia dan kehancuran bangunan (Latief dkk., 2006).

Sebaran genangan yang tejadi di wilayah pesisir dimodelkan dengan menggunakan persamaan Berryman (2005) dalam Purbani dkk. (2013). Persamaan tersebut menggunakan parameter nilai kekasaran permukaan, kelerengan lahan (slope) dan tinggi gelombang datang. Nilai kekasaran permukaan diperoleh dari analisis tutupan lahan hasil olahan citra satelit Bing Maps yang digitasi pada layar (onscreen). Nilai koefisien kelerengan lahan ditunjukkan pada tabel 1 menurut hasil penelitian koefisien kekasaran lahan (mannings coefficients of roughness) oleh Aida dan Kotani, dkk dalam Permana (2010). Untuk menghitung jarak rendaman, tinggi gelombang tsunami di garis pantai di asumsikan sebagai nilai run-up hasil perhitungan dengan menggunakan persamaan (8). Nilai kelerengan lereng (slope) diper- oleh dari Peta Rupa Bumi Indonesia, dan pemodelan penguarangan ketinggian tsunami di daratan dijabarkan dalam persamaan:

$$
H_{\text {lass }}=\frac{167 n^{2}}{H_{o}^{2 / 3}}+5 \sin S
$$

dengan $H_{\text {loss }}$ adalah hilangnya ketinggian tsunami per $1 \mathrm{~m}$ dari jarak inundasi, n adalah koefisien kekasaran permukaan, $H_{0}$ adalah ketinggian gelombang tsunami di garis pantai dan $\mathrm{S}$ adalah besarnya lereng permukaan.

Berdasarkan Sebaran genangan yang terjadi di wilayah pesisir selatan Kabupaten Bulukumba dapat diketahui wilayah mana saja yang rentan terhadap inundasi akibat tsunami. Langkah akhir dilakukan proses pembuatan peta tingkat kerentanan genangan tsunami dengan melakukan tumpang susun (overlay) dengan peta tematik, peta kelerengan lahan, peta fungsi lahan, dan peta genangan hasil pemodelan run-up 17 (berdasarkan hasil perhitungan untuk gempabumi tanggal 3 Maret 1927) dan $25 \mathrm{~m}$ (berdasarkan data historis untuk gempabumi tanggal 29 Desember 1820).

\section{HASIL DAN DISKUSI}

\subsection{Tata Guna Lahan dan Kemiringan Lereng}

Survei di lapangan telah dilakukan sebagai kontrol (groundcheck) terhadap peta citra satelit Bing Maps dan topografi SRTM-61 pada tanggal 11 Maret 2016. Secara umum hasil survei terhadap tutupan lahan yang diperoleh tidak berbeda jauh dengan citra satelit. Hasil pengamatan di beberapa lokasi menunjukkan bahwa jenis lahan yang ditemukan di lapangan masih konsisten dengan pencitraan Bing Maps pada tanggal 29 Maret 2016.

Secara umum, klasifikasi tutupan lahan yang terdapat di wilayah pesisir Kabupaten Bulukumba hampir di setiap Kecamatan didominasi oleh pemukiman padat bangunan. Secara khusus, sepanjang pesisir pantai Kecamatan Gantarang saat ini didominasi oleh sawah, lahan kosong dan vegetasi dengan kerapatan sedang.

Klasifikasi tutupan lahan di sepanjang wilayah pesisir Kecamatan Ujungbulu lebih banyak didominasi dengan pemukiman padat bangunan. Sedangkan lahan di Kecamatan Ujung Loe banyak digunakan untuk sawah, namun kategori lahan pemukiman sedang bangunan juga ditemukan di wilayah pesisir. Tutupan lahan di wilayah pesisir Kecamatan Bontotiro dan Kecamatan Bontobahari didominasi oleh vegetasi kerapatan sedang. Dari hasil survei lapangan, sangat jarang ditemukan ekosistem magrove di sekitar wilayah pesisir Kabupaten Bulukumba. Hanya saja terdapat tembok penghalang di pinggir pantai untuk mengurangi tinggi gelombang yang masuk ke daratan.

Langkah awal pengolahan data pada penelitian ini yaitu menghasilkan peta citra daerah penelitian yang disajikan dalam Gambar 2.

Peta citra daerah penelitian tidak mengambil satu luasan Kabupaten Bulukumba, tetapi hanya wilayah pesisir yang berpotensi terkena gelombang tsunami dengan luas wilayah $355,003 \mathrm{~km}^{2}$. Luas wilayah tersebut terdiri dari $6 \mathrm{ke}-$ camatan, yaitu Kecamatan Gantarang dengan luas wilayah pesisir 132,726 km², Kecamatan Bulukumpa dengan luas $0,9425 \mathrm{~km}^{2}$, Kecamatan Bontobahari dengan luas wilayah 


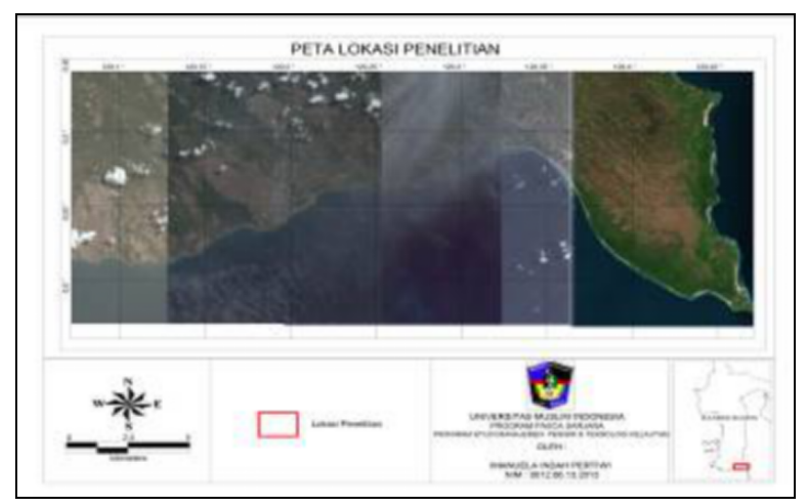

Gambar 2. Peta citra daerah penelitian.

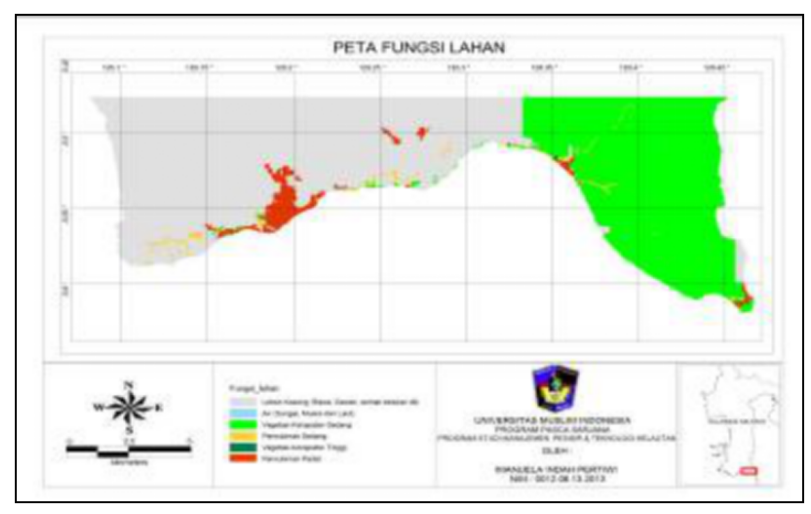

Gambar 3. Peta fungsi lahan.

pesisir 114,569 $\mathrm{km}^{2}$, Kecamatan Bontotiro dengan luas wilayah pesisir $23,206 \mathrm{~km}^{2}$, Kecamatan Ujungbulu dengan luas wilayah pesisir $27,784 \mathrm{~km}^{2}$, dan Kecamatan Ujung Loe dengan luas wilayah Pesisir $55,773 \mathrm{~km}^{2}$. Peta tersebut merupakan gabungan dari semua capture citra satelit Bing Maps pada daerah penelitian yang diambil pada tanggal 29 Maret 2016. Citra Bing Maps pada daerah penelitian di-capture dengan zoom 20. Peta citra tersebut kemudian digrid dengan jarak antar grid adalah $50 \mathrm{~m}$. Grid pada peta bertujuan untuk memudahkan digitasi koefisien fungsi lahan dengan software MapInfo sehingga menghasilkan peta fungsi lahan untuk daerah penelitian pesisir Kabupaten Bulukumba seperti ditunjukkan dalam Gambar 3.

Berdasarkan peta koefisien kekasaran/fungsi lahan ini dapat diketahui luasan lahan sesuai dengan kategori lahan. Lahan di wilayah pesisir Kabupaten Bulukumba didominasi oleh lahan kosong, rawa, dan sawah seluas $205,92 \mathrm{~km}^{2}$ atau sekitar $58 \%$ dari luas wilayah penelitian. Vegetasi dengan kerapatan sedang mendominasi dengan luas 133,313 km2 atau sekitar $37.55 \%$ dari luas wilayah penelitian. Kategori lahan pemukiman padat bangunan dan pemukiman sedang bangunan juga banyak ditemukan di wilayah pesisir dengan luas berturut-turut adalah $10,56 \mathrm{~km}^{2}$ dan $4,459 \mathrm{~km}^{2}$ atau sekitar $2.97 \%$ dan $1.25 \%$ dari luas wilayah penelitian. Hanya sedikit lahan di wilayah pesisir Bulukumba berkategori vegetasi kerapatan tinggi.

Sudut kelerengan lahan (slope) Kabupaten Bulukumba diperoleh dari hasil pengolahan data topografi di ArcGis. Peta koefisien kelerengan lahan (slope) untuk daerah peneli-

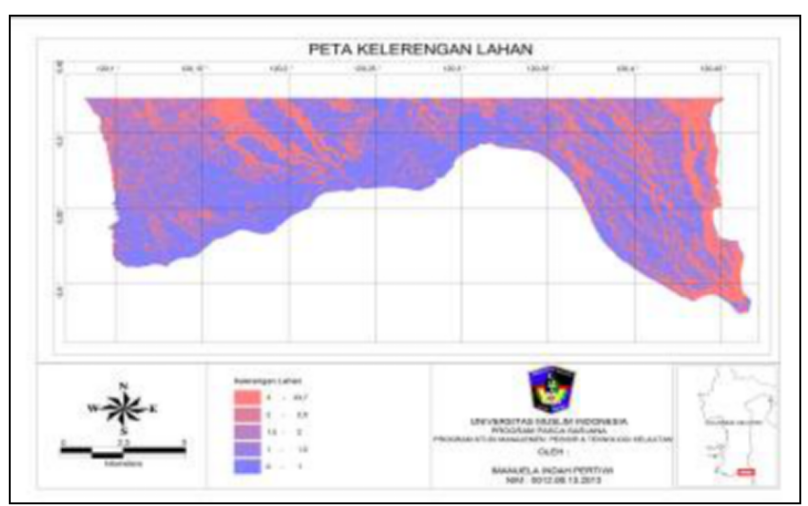

Gambar 4. Peta fungsi lahan.

tian pesisir Kabupaten Bulukumba seperti ditunjukkan dalam Gambar 4.

Berdasarkan peta kelerengan lahan, dapat dilihat bahwa wilayah pesisir Kabupaten Bulukumba yang menjadi daerah penelitian memiliki kelerengan lahan 0 - 33,68 ${ }^{\circ}$. Kelerengan lahan tertinggi ada di Kecamatan Gantarang dan semakin ke timur kelerengan lahan wilayah pesisirnya adalah landai.

\subsection{Potensi Gempabumi}

Berdasarkan data historis kejadian gempabumi di Laut Flores gempabumi yang pernah terjadi yang memiliki potensi menimbulkan tsunami adalah gempabumi magnitudo 7.1 SR dan 7.5 SR. Data gempabumi yang digunakan untuk menghitung periode ulang kejadian gempabumi adalah data periode 89 tahun, yaitu tahun 1927 sampai 2 November 2016 dengan magnitudo gempa yang bervariasi antara 3-7 (data kejadian gempabumi terlampir). Menggunakan persamaan Gutenberg-Richter, persamaan 1, dengan magnitude completeness adalah 4.0, dapat diketahui tingkat seismisitas dan periode ulang gempabumi. Tingkat seismisitas (aktifitas seismik) dinyatakan dalam dua variabel yaitu nilai-a dan nilai-b. Nilai-b yang merupakan parameter tektonik yang menggambarkan sifat batuan di Laut Flores sebesar 0.6908 sedangkan nilai-a yang menggambarkan aktivitas tektonik di Laut Flores sebesar 5.514. Nilai-a tersebut merupakan aktivitas tektonik untuk gempabumi dengan magnitudo diatas 7 (M 7) yang artinya rata-rata per tahun gempabumi dengan magnitudo M 7 terjadi sebanyak 5 kali. Berdasarkan pada kedua variabel tersebut, dengan menggunakan persamaan 5 dapat diketahui periode ulang terjadinya gempa dengan magnitudo 7.1 dan 7.5 yaitu 22 tahun dan 41 tahun. Hal ini artinya bahwa gempabumi dengan skala magnitudo 7.1 akan terulang kembali di daerah ini pada kurun waktu 22 tahun dari waktu terjadinya. Dalam hal ini gempa dengan magnitudo 7.1 terjadi pada tahun 1927, sehingga secara statistik diperkirakan gempabumi ini akan terulang pada tahun 1949. Untuk gempabumi dengan skala magnitudo 7.5 akan terulang kembali di daerah ini dalam kurun waktu 41 tahun dari waktu terjadinya. Gempabumi 7.5 diketahui terjadi pada tahun 1820, sehingga secara statistik diperkirakan akan terulang terjadi pada tahun 1861. Dilihat dari sejarah kegempaan, terjadi gempabumi pada tahun 1949 di Laut Flores dengan magnitude 6.4, sedangkan pada tahun 1861 tidak 
Tabel 2. Hubungan magnitudo dan tinggi tsunami di pantai (Iida, 1963)

\begin{tabular}{|l|l|l|l|}
\hline Magnitudo & Log (Hr) & Hr (m) & $\begin{array}{l}\text { Magnitudo } \\
\text { tsunami } \\
\text { Iida }\end{array}$ \\
\hline 7.10 & 1.25 & $17.78(17)$ & 4.15 \\
\hline 7.50 & 1.45 & $28.18(28)$ & 4.81 \\
\hline
\end{tabular}

ditemukan terjadi gempabumi di Laut Flores. Hal ini disebabkan karena Laut Flores merupakan wilayah yang aktif dari segi kegempaan karena terletak dekat daerah subduksi, sehingga sering terjadi gempabumi berskala kecil. Karena adanya pelepasan energi yang berlangsung terus menerus, diperkirakan terjadinya pelepasan energi dalam skala besar yang menyebabkan gempabumi besar, dalam hal ini gempa dengan magnitudo lebih besar dari 7,5 dalam jangka waktu yang lama.

\subsection{Potensi Tsunami}

Dalam penelitian ini, perhitungan tinggi run-up tsunami dilakukan pada magnitudo gempabumi yang pernah terjadi dan yang memiliki potensi menimbulkan tsunami di Laut Flores. Hasil perhitungan dengan menggunakan persamaan 8, diperoleh perkiraan tinggi tsunami serta skala kekuatan relatif dari tsunami (magnitude tsunami) 7.1 dan 7.5 pada Tabel 2

Hasil perhitungan menunjukkan bahwa potensi tsunami di Laut Flores sangat berbahaya. Besar magnitudo tsunami yang diperoleh juga bersesuaian dengan tabel hubungan magnitudo tsunami dan tinggi tsunami di pantai yang telah ditentukan oleh Iida, 1963 (Tabel 1). Pemodelan kerentanan dampak/efek tsunami secara spasial digunakan run-up 17 $\mathrm{m}$ yang diperoleh berdasarkan persamaan untuk magnitudo yang berpotensi tsunami $(7,1)$, dan $25 \mathrm{~m}$ dipilih untuk magnitudo 7,5 berdasarkan data lapangan saat kejadian (sumber : Tsunami Catalogue and Zones in Indonesia dalam Journal of Natural Disaster Service).

Pemodelan jangkauan genangan (inundasi) tsunami diperoleh dengan memasukan nilai koefisien fungsi lahan dan sudut kelerengan lahan untuk setiap variasi ketinggian run-up pada Tabel 1 ke dalam persamaan 11. Proses pemodelan untuk menghitung penurunan ketinggian tsunami terhadap faktor fungsi lahan dan kelerengan lahan pada penelitian ini berasumsi bahwa arah gerak gelombang tsunami mayoritas dari Selatan ke Utara, tidak bergerak ke arah lain mengikuti topografi yang rendah sebagaimana lazimya pergerakan air. Akibatnya, menurut Berryman (2006), model ini akan cenderung kurang teliti untuk jarak jangkauan inundasi. Hasil perhitungan tersebut kemudian ditampilkan ke dalam peta inundasi tsunami hasil pemodelan untuk setiap variasi ketinggian run-up di setiap kecamatan.

Dalam analisa SIG, zona inundasi hasil pemodelan dioverlay dengan batas tiap kecamatan di Kabupaten Bulukumba, sehingga luas dan jangkauan genangan. Kekasaran permukaan yang mempunyai nilai koefisien tinggi mampu menghadang genangan tsunami seperti pemukiman dan gedung bertingkat. Sebaliknya nilai koefisien kekasaran permukaan yang kecil memilki faktor hambatan yang kecil terhadap genangan tsunami yang masuk ke daratan seperti lahan kosong. Pada wilayah yang memiliki tutupan lahan

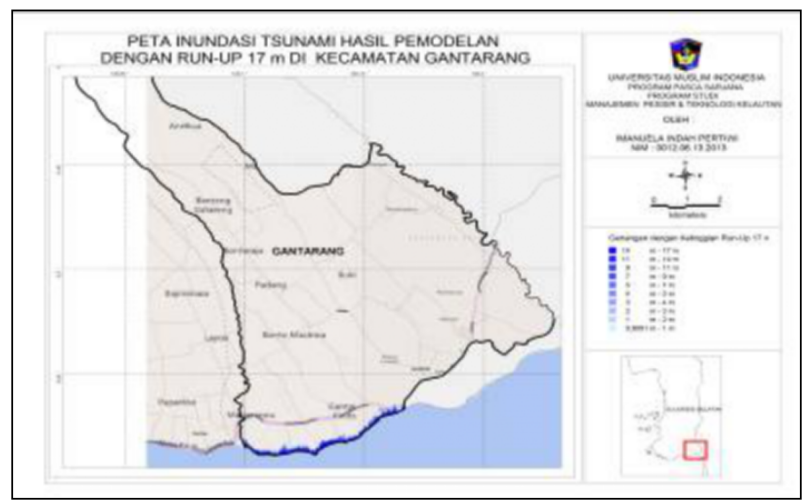

Gambar 5. Peta inundasi tsunami hasil pemodelan dengan runup $17 \mathrm{~m}$ di Kecamatan Gantarang.

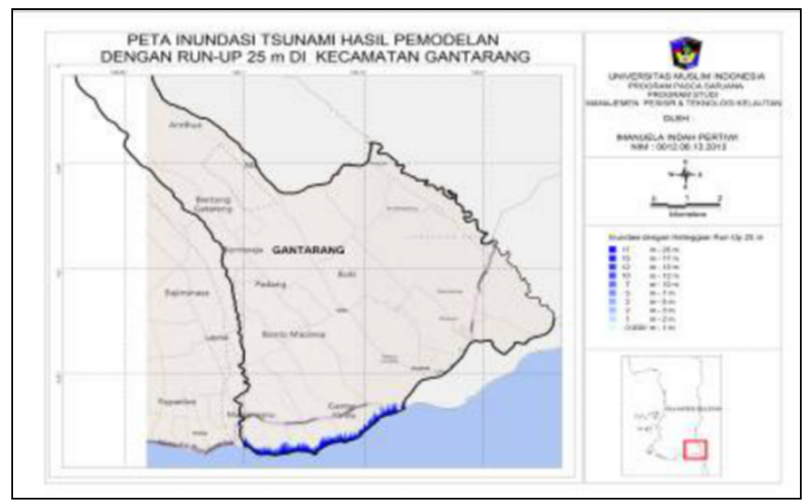

Gambar 6. Peta inundasi tsunami hasil pemodelan dengan runup 25 m di Kecamatan Gantarang

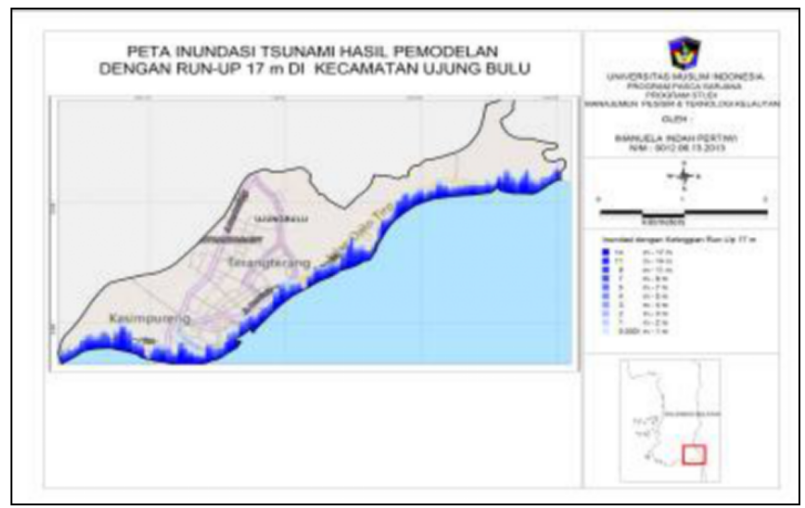

Gambar 7. Peta inundasi tsunami hasil pemodelan dengan runup $17 \mathrm{~m}$ di Kecamatan Ujungbulu.

yang didominasi oleh pemukiman padat bangunan dengan nilai koefisien kekasaran yang tinggi menyebabkan genangan tsunami teredam dengan baik. Faktor kelerengan lahan juga sangat mempengaruhi hambatan genangan tsunami yang masuk ke daratan. Topografi wilayah yang meninggi sangat baik dalam meredam genangan tsunami. 


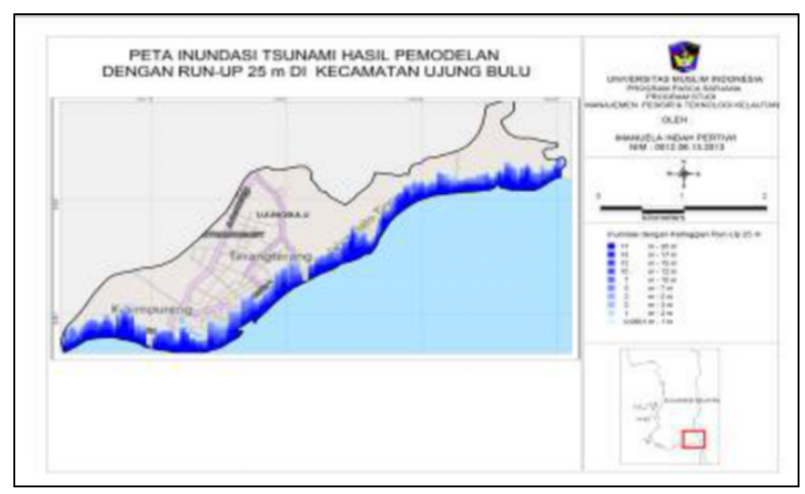

Gambar 8. Peta inundasi tsunami hasil pemodelan dengan runup $25 \mathrm{~m}$ di Kecamatan Ujungbulu.

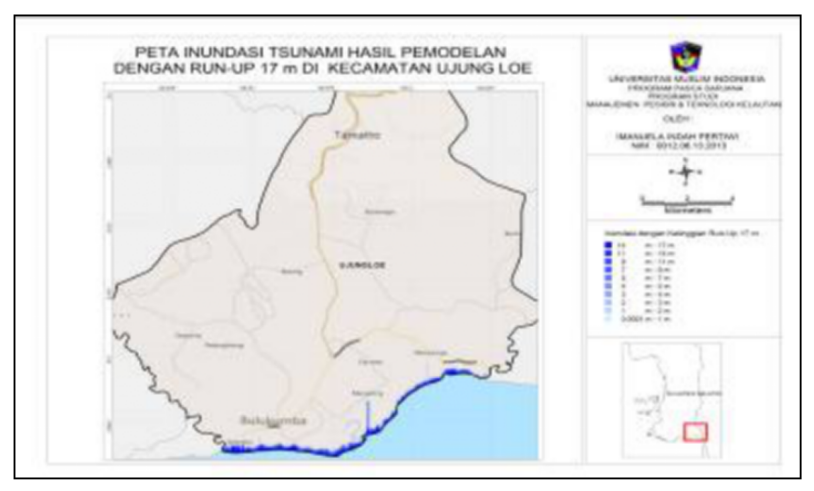

Gambar 9. Peta inundasi tsunami hasil pemodelan dengan runup $17 \mathrm{~m}$ di Kecamatan Ujung Loe.

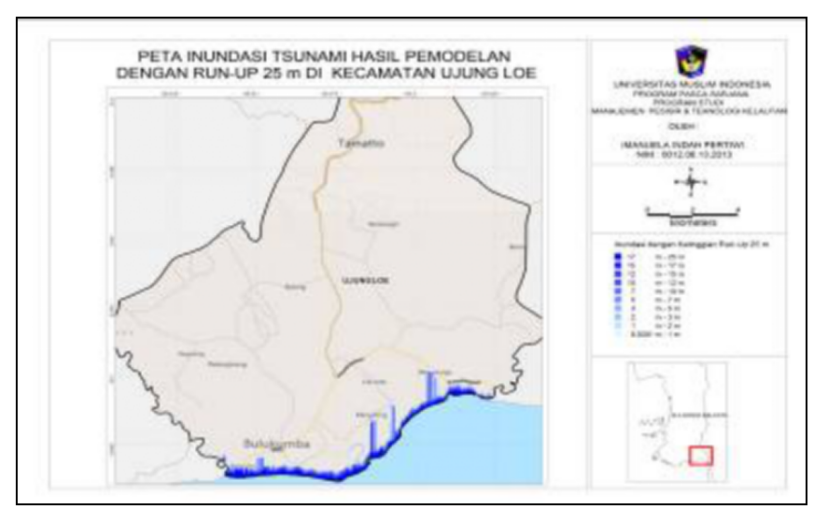

Gambar 10. Peta inundasi tsunami hasil pemodelan dengan runup 25 m di Kecamatan Ujung Loe

\subsection{Mitigasi Bencana Tsunami}

Badan Pusat Statistik Kabupaten Bulukumba Tahun 2015 mencatat bahwa penggunaan lahan di Kabupaten Bulukumba secara garis besar dibagi dalam tiga macam penggunaan lahan, yaitu lahan sawah, lahan pertanian bukan sawah, dan lahan bukan pertanian. Lahan sawah digunakan untuk irigasi yang secara umum ditanami tanaman padi dan tadah hujan. Lahan pertanian terdiri dari tegal/kebun, hutan rakyat, kolam, dan padang rumput. Pada lahan pertanian sebagian besar ditanami tanaman buah-

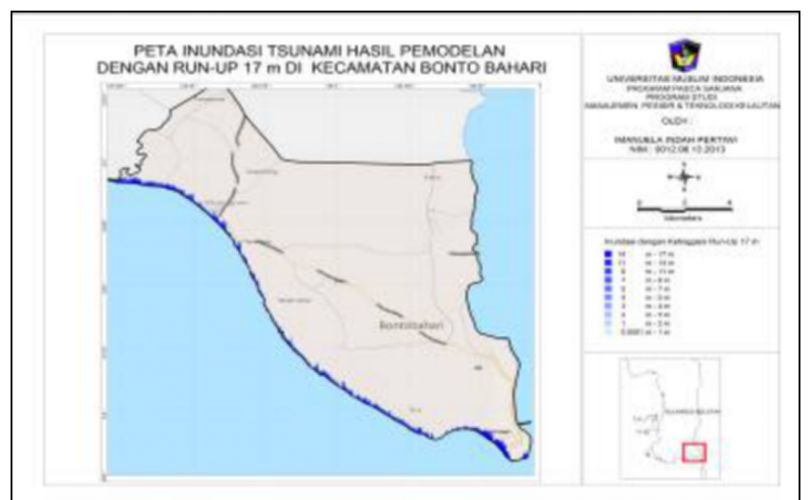

Gambar 11. Peta inundasi tsunami hasil pemodelan dengan runup $17 \mathrm{~m}$ di Kecamatan Bontobahari

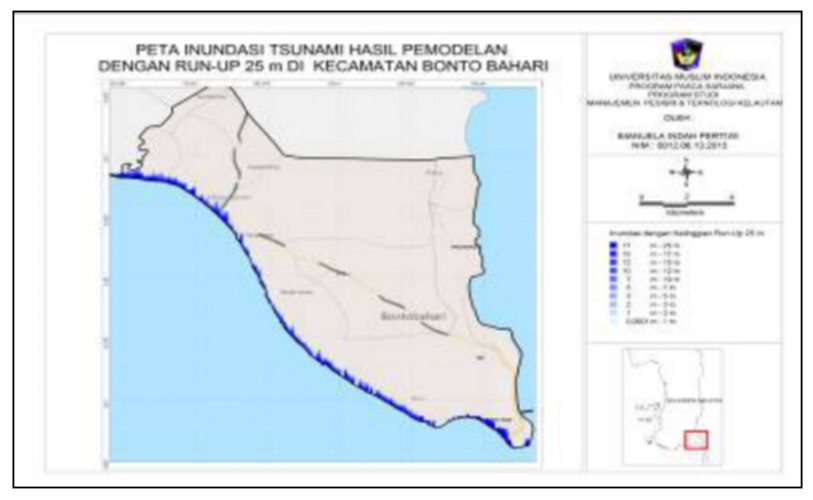

Gambar 12. Peta inundasi tsunami hasil pemodelan dengan runup $25 \mathrm{~m}$ di Kecamatan Bontobahari.

buahan, kacang-kacangan, dan umbi-umbian. Lahan ini juga ditanami dengan tanaman perkebunan besar seperti kakao, kopi, karet, kelapa, cengkeh, dan lada. Sedangkan lahan bukan pertanian adalah lahan yang sama sekali tidak digunakan untuk kegiatan pertanian meliputi perumahan, hutan negara, jalan, dan sungai. Luas lahan bukan pertanian mengalami penurunan akibat adanya penambahan lahan pertanian. Namun tidak dapat dipungkiri, bahwa di Kabupaten Bulukumba telah mulai terjadi alih fungsi lahan pertanian menjadi perumahan serta industri.

Berdasarkan pada tabel di atas, terlihat bahwa hampir seluruh Kecamatan terkena genangan tsunami, kecuali Kecamatan Bulukumpa yang tidak berbatasan langsung dengan garis pantai. Secara umum, luas area inundasi tsunami di Kabupaten Bulukumba adalah 13,617 $\mathrm{km}^{2}$ atau $3.836 \%$ dari luas wilayah pesisirnya. Luas genangan tsunami di setiap kecamatan berbeda-beda tergantung pada lebar wilayahnya yang berbatasan dengan garis pantai.

Secara detail diketahui bahwa Kecamatan Bontobahari mengalami genangan terluas sebesar $4,371 \mathrm{~km}^{2}$ atau $3.815 \%$ dari luas wilayah pesisirnya, dengan inundasi terjauh 0,55 $\mathrm{km}$ dari garis pantai. Hal ini disebabkan karena luas wilayah pesisirnya didominasi oleh pohon dan padang penggembalaan/rumput, serta kelerengan lahan yang landai. Namun jangkauan inundasi terjauh ada di Kecamatan Ujung Loe yaitu $1,65 \mathrm{~km}$ dari garis pantai. Hal tersebut terlihat dari kategori fungsi lahan di wilayah pesisirnya yang didominasi oleh sawah dan tambak, serta kelerengan lahan yang 
landai. Kecamatan Gantarang yang hampir seluruh wilayahnya didominasi oleh sawah memiliki luas genangan dan jangkauan inundasi tsunami kecil, disebabkan karena kecamatan ini memiliki kelerengan lahan (slope) wilayah pesisir yang tinggi. Kecamatan Ujungbulu merupakan kecamatan yang fungsi lahan di wilayah pesisirnya digunakan sebagai area pemukiman berkategori pemukiman padat bangunan. Nilai koefisien kekasaran/fungsi lahan yang tinggi, menyebabkan tsunami dapat teredam dengan baik. Hal ini dapat dilihat dari jangkauan genangan tsunami sampai $0,6 \mathrm{~km}$. Tetapi fungsi lahan di wilayah pesisir Ujungbulu sangat tidak baik karena akan menimbulkan korban jiwa sekitar 12.118 jiwa (sumber : data kepadatan penduduk BPS Kabupaten Bulukumba Tahun 2015). Kecamatan Bontotiro adalah kecamatan yang paling kecil terkena genangan tsunami, karena hanya sedikit luasan wilayahnya yang berbatasan langsung dengan garis pantai serta adanya vegetasi yang berkategori vegetasi kerapatan sedang.

Mitigasi bencana sebagai upaya untuk mengurangi dampak dari bencana tsunami sangat perlu untuk dilakukan. Melihat hasil simulasi pemodelan dengan asumsi tinggi run-up tsunami yang ekstrim, perlu adanya upaya perencanaan dan pengelolaan tata ruang wilayah yang baik di wilayah pesisir Kabupaten Bulukumba, diantaranya yaitu: (i) Sejalan dengan konsep pengelolaan lingkungan hidup yang lestari dalam pembangunan berkelanjutan, akan lebih baik dan bijaksanan jika Pemerintah Kabupaten Bulukumba memprioritaskan wilayah pesisir untuk dijadikan kawasan konservasi hutan pantai (tanaman mangrove) yang juga berfungsi sebagai sabuk hijau penahan gelombang tsunami. (ii) Perlu adanya aturan yang mengatur tentang pembangunan rumah, industri, dan bangunan lainnya di wilayah pesisir. Tetapi jika kondisi wilayah pesisir akan dijadikan sebagai daerah pemukiman maupun ruang publik seperti di Kecamatan Ujungbulu, hendaknya fisik bangunan mengikuti kaidah konstruksi tahan gempa dan tsunami. Untuk bangunan publik seperti pusat perbelanjaan ataupun hotel hendaknya dibuat model panggung sehingga ketika tsunami datang tidak akan menerjang dinding bangunan tetapi melewati lorong dibawahnya. Bangunan dengan bentuk panggung di wilayah pesisir ini juga bisa berfungsi sebagai shelter perlindungan dari tsunami.

\section{KESIMPULAN}

Berdasarkan hasil penelitian dapat disimpulkan :

(i) Potensi kegempaan di Laut Flores tinggi dengan kekuatan (magnitude) yang berpotensi menimbulkan tsunami di sekitarnya, tidak terkecuali Kabupaten Bulukumba.

(ii) Berdasarkan sejarah kejadian gempabumi, tinggi runup tsunami yang ditimbulkan adalah $17 \mathrm{~m}$ dan $25 \mathrm{~m}$.

(iii) Dari hasil pemodelan diketahui bahwa luas area inundasi tsunami di Kabupaten Bulukumba sebesar 3.836\% dari luas wilayah pesisir, yaitu $13,617 \mathrm{~km}^{2}$. Wilayah pesisir Kecamatan Ujungbulu merupakan area pemukiman padat yang memiliki resiko tertinggi terhadap tsunami dengan estimasi genangan seluas $3,331 \mathrm{~km}^{2}$. Tutupan lahan di wilayah pesisir Kecamatan Bontotiro yang berupa vegetasi dengan interval jarak lebih dari $3 \mathrm{~m}$ terlihat mampu meredam tsunami dengan ketinggian $17 \mathrm{~m}$ dan $25 \mathrm{~m}$. (iv) Salah satu skenario mitigasi bencana tsunami di Kabupaten Bulukumba yaitu menjadikan wilayah pesisir untuk sebagai kawasan konservasi hutan pantai (tanaman mangrove) yang berfungsi sebagai sabuk hijau penahan gelombang tsunami.

\section{UCAPAN TERIMA KASIH}

Penulis mengucapkan terima kasih kepada Kedua Orang Tua; Bapak Sukadi dan Ibu Corry Misalayuk, Suami Amir Abidin, saudara, serta Dosen Pembimbing sebagai Tim Penulis yang telah memberikan doa, dukungan ilmu dalam penyelesaian penelitian ini.

\section{DAFTAR PUSTAKA}

Abe, K., 1995, Estimate of Tsunami Run-up Heights from Earthquake Magnitudes, in Tsunami : Progress and Warning, Editors Tsuchiya, Y. And Shuto, N., Kluwer Academic Publishers Dordrecht, Boston, London.

Aki K., 1965, Maximum Likelihood Estimate of b value in The Formula $\log N=a-b M$ and Its Confidence Limits. Bull. Earthq. Res. Inst. 43,237-240.

Berryman, K., 2006. Review of Tsunami Hazard and Risk in New Zealand. Lower Hutt : Institute of Geological and Nuclear Sciences.

Diposaptono, S., 2003. Mitigasi Bencana Alam di Wilayah Pesisir dalam Kerangka Pengelolaan Wilayah Pesisir Terpadu. Alami, Vol.8.

Diposaptono, S dan Budiman. 2006, Tsunami. Buku Ilmiah Populer, Jakarta.

Hamzah, L. Puspita, N.T. and Imamura, F., 2000, Tsunami Catalogue and Zones in Indonesia. Journal of Natural Disaster Service, 22, 1, 25-43, Hal : 39 .

Iida, K., 1963. Magnitude, Energy, and Generation Mechanisms of Tsunami and A Catalogue of Earthquakes associated with Tsunamis, in Proceedings, Tsunami Meetings Associated with The Tenth Pacific Science Congress, pp. 7-10, Int. Union of Geod. And Geophys., Paris.

Latief, H., H. Sunendar, Yuhsananta. P, dan E. Riawan. 2006, Pemodelan dan 1Pemetaan Rendaman Tsunami serta Kajian Resiko Bencana Tsunami Kota Padang. PPKPL, ITB.

Permana, D., 2010, Analisis Pemodelan Inundasi Tsunami Terhadap Jenis Tutupan Lahan Di Kota Bengkulu. Tesis, Program Studi PascaSarjana Pengelolaan Sumberdaya Alam dan Lingkungan, Fakultas Pertanian, Universitas Bengkulu, Bengkulu.

Purbani, D., M.F. Boer, Marimin, I.W. Nurjaya dan F. Yulianda. 2013. Kemampuan Ekosistem Mangrove Dalam Mereduksi Tsunami di Teluk Loh Pria Laot Pulau Weh. Jurnal Segara Vol. $9: 95-106$.

Perda RTRW No. 21 Tahun 2012 Kabupaten Bulukumba

Roorda van Eysinga, S., 1830. Journaal mijner re is van Batavia naar Makassar en de Moluksche Eilanden. In Verschillende Reizen En Lotgevallen, (Amsterdam: van der Hey), pp. 173179

USGS, Probabilistic Seismic Hazard Analysis. http://earthquake.usgs.gov/ research/hazmaps/ product_data/

Yasid,M., 1999, Studi Seismotektonik Pulau Bali danSekitarnya Berdasarkan Relokasi Hiposenter dan Solusi Bidang Sesar. Tugas Akhir, Program StudiGeofisika, Jurusan Geofisika dan Meteorologi,Fakultas Matematika dan Ilmu Pengetahuan Alam, Institut Teknologi Bandung, Bandung.

Badan Pusat Statistik Kabupaten Bulukumba Tahun 2015 (https://bulukumbakab.bps.go.id)

www.globalcmt.org/CMTsearch.html diakses pada tanggal 7 Januari 2016. 